\title{
Clinical and Radiological Early Results of Acetabulum Fractures Operated with the Modified Stoppa Approach
}

\author{
Modifiye Stoppa Yöntemiyle Yaptığımız Asetabulum Kırıklarının Erken Dönem \\ Klinik ve Radyolojik Sonuçları
}

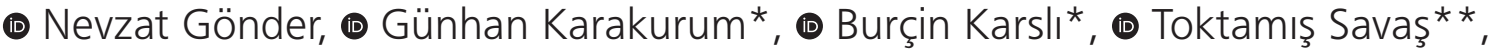 \\ (1) Nurcihan Yavuz Savaş***
}

islahiye State Hospital, Clinic of Orthopedics and Traumatology, Gaziantep, Turkey

*Gaziantep University Faculty of Medicine, Şahinbey Training and Research Hospital, Clinic of Orthopedics and Traumatology, Gaziantep, Turkey

**Ceylanpınar State Hospital, Clinic of Orthopedics and Traumatology Şanlıurfa, Turkey

${ }^{* * * C e y l a n p ı n a r ~ S t a t e ~ H o s p i t a l, ~ C l i n i c ~ o f ~ R a d i o l o g y, ~ S ̧ a n l ı u r f a, ~ T u r k e y ~}$

\section{Abstract}

Aim: To evaluate the follow-up results of patients hospitalized for acetabular fractures and treated with the modified Stoppa approach.

Methods: Records of fifty-two Acetabula from 48 patients who were followed up for at least six months between 2016 and 2019 were retrospectively analyzed. All fractures were classified according to the Judet-Letournel classification along with direct $\mathrm{X}$-rays and 3D computed tomography findings. The postoperative reduction quality and radiological assessments during follow-up visits were evaluated according to Matta's reduction quality criteria and Matta's radiological scoring system. The clinical outcomes were analyzed using the modified Merle d'Aubigné scoring system.

Results: The mean follow-up period of 48 patients included in the study was 9.72 (6-26) months. Excellent clinical results were obtained in 38 acetabula (73\%). A significant correlation was found between the reduction quality assessment performed on the postoperative $X$-rays and the clinical outcome $(p=0.002)$. At the same time, there was a significant correlation between Matta's radiological criteria and clinical outcomes $(p<0.001)$.

Conclusion: This study shows that reduction quality in acetabular fractures and anatomical reduction done with stable fixation under optimal conditions is strongly associated with clinical outcomes.

Keywords: Acetabulum, pelvis, traumatology
Amaç: Asetabulum kırığı nedeniyle yatırılan ve modifiye Stoppa yöntemiyle tedavi edilen hastaların takip sonuçlarını değerlendirmektir.

Yöntemler: Çalışmaya 2016-2019 yılları arasında en az altı ay izlemi olan 48 hastanın 52 asetabulumu dahil edildi. Veriler retrospektif olarak analiz edildi. Kırıkların tümü elde edilen direk grafi ve üç boyutlu bilgisayarlı tomografi bulguları ile Judet-Letournel sınıflamasına gore sınıflandırıldı. Hastaların postoperative redüksiyon kalitesi ve takiplerdeki radyolojik değerlendirmeleri Matta'nın redüksiyon kalitesi ve Matta'nın Radyolojik Evreleme sistemine göre yapıldı. Klinik sonuçlar Modifiye Merle D'Aubigne Değerlendirme ölçeği'ne göre değerlendirildi.

Bulgular: Çalışmaya dahil edilen 48 hastanın ortalama takip süresi 9,72 (6-26) ay idi. Otuz sekiz asetabulumda (\%73) mükemmel klinik sonuç elde edildi. Hastaların postoperatif röntgenlerinde yapılan redüksiyon kalitesi değerlendirmesi ile klinik sonuç arasında anlamlı bir korelasyon bulundu $(p=0,002)$. Aynı zamanda Matta'nın radyolojik kriterleri ile klinik sonuçlar arasında anlamlı bir korelasyon vardı $(p<0,001)$.

Sonuç: Bu çalışma bize asetabulum kırıklarında redüksiyon kalitesinin, optimum şartlarda stabil fiksasyonla yapılan anatomic redüksiyonun klinik sonuçlarla kuvvetli ilişkili olduğunu göstermektedir.

Anahtar Sözcükler: Asetabulum, pelvis, travmatoloji
Address for Correspondence/Yazışma Adresi: Nevzat Gönder, İslahiye State Hospital, Clinic of Orthopedics and Traumatology, Gaziantep, Turkey

E-mail: n_gonder_02@hotmail.com ORCID: orcid.org/0000-0003-0691-1289

Received/Geliş Tarihi: 18 July 2020 Accepted/Kabul Tarihi: 07 October 2020

This study was presented in the Turkish Orthopedics and Traumatology Congress on October 22-27 2019 and took part in the abstract book.
${ }^{\circ}$ Copyright 2020 by The Medical Bulletin of istanbul Haseki Training and Research Hospital The Medical Bulletin of Haseki published by Galenos Yayinevi. 'Telif Hakkı 2020 istanbul Haseki Eğitim ve Araștırma Hastanesi Haseki Tip Bülteni, Galenos Yayınevi tarafindan yayınlanmıştır. 


\section{Introduction}

The incidence of high-impact injuries has increased due to increased vehicle use and hectic pace of working and social life. As a result, the number of patients who suffer from acetabular fractures is also increasing. The treatment of acetabular fractures still remains a major issue due to the complex anatomy of the acetabular region, challenges with reaching the fracture site, its rarity compared to other injuries, the complex nature of surgical procedures, and potential complications (1).

Studies have shown that as with all intra-articular fractures, ensuring anatomical reduction, stable internal fixation and early joint movement are important for acetabular fractures; and that the primary factor influencing the clinical outcome is reduction quality (1-5). For this reason, surgical treatment aims to prevent and delay posttraumatic arthrosis, which is the most important late-stage complication of acetabular fractures (6).

The modified Stoppa approach has recently become more popular. The advantages of the modified Stoppa method include easy access to the quadrilateral surface, possibility to perform direct and indirect reduction, less invasiveness and less damage to the soft tissue. In this study, we aimed to compare clinical and radiological findings of patients with acetabular fractures, who were treated with the modified Stoppa approach and followed up adequately, with other studies in the literature.

\section{Methods}

\section{Study Design}

This clinical trial was performed after obtaining approval from Gaziantep University Clinical Research Ethics Committee (decision no: 2019/256, date: 19.06.2019).

The study population comprised of 48 patients (52 acetabula) who were treated in the orthopedics and traumatology clinic at Gaziantep University Faculty of Medicine due to acetabular fracture between 2016 and 2019 and followed up for at least six months following treatment and volunteered to participate in the study.

\section{Exclusion Criteria:}

a. Patients not followed up sufficiently

b. Fractures of the isolated posterior acetabulum

c. Those with a previous history of peritonitis or pelvic inflammatory diseases

d. Those who had pelvic surgery such as C-section, hysterectomy, and bladder surgery

e. Pathological fractures

f. Open fractures

g. Patients followed up conservatively

\section{Clinical Evaluation}

The data collection flow was carried out as follows: Orthopedic and general systemic examinations of all patients admitted were performed in the emergency room. Standard X-rays of the anterior and posterior pelvis and the obturator-iliac oblique were taken apart from direct $X$-rays performed due to additional findings during the examination of patients. Firstly, the patients were stabilized; afterwards, a 3-dimensional pelvic computed tomography was taken as a standard procedure. All patients were applied skeletal traction on the femoral supracondylar region. All patients had urinary catheter inserted as a precaution against injuries of the urogenital system; hematuria was monitored, and urological consultation was requested. For cases of abdominal sensitivity, chest trauma and head trauma, the relevant departments were asked for a consultation. The patients were operated on the $2^{\text {nd }}$ day of the trauma at the earliest, and on the 24th day of the trauma at the latest. Antimicrobial prophylaxis with $1,000 \mathrm{mg}$ cefazolin was administered before surgery and continued for at least 24 hours afterwards. For prophylaxis against heterotopic ossification, the patients received 75 $\mathrm{mg} /$ day indomethacin for eight weeks postoperatively. A treatment regimen with low molecular weight heparin was given for prophylaxis against deep vein thrombosis (DVT) until the end of the first postoperative month after patients were hemodynamically stabilized. The patients were prescribed passive exercises in bed on the first operative day, to the extent they tolerated. Depending on their clinical condition, they practiced active exercises from the days 2 or 3 and were mobilized with crutches to prevent strains on the operated joints. The sutures were removed on the $15^{\text {th }}$ day after discharge, and the patients were invited for a follow-up visit after an average of four weeks. Standard X-rays of the anterior and posterior pelvis, iliac and obturator oblique were taken during the follow-up visit. The patients were mobilized with partial weight bearing on the week $6^{\text {th }}$ on average and full weight bearing on the week 10th. Fifty-two acetabula of 48 patients who were followed up for at least six months for a thorough final assessment were included in the study.

Clinical assessment of patients during their final follow-up visit was made according to the Modified Merle d'Aubigne clinical evaluation criteria. According to this scoring system, 18 points are interpreted as "excellent", 15-17 points "good", 12-14 points "average" and 3-11 points "poor" (7).

Postoperative reduction quality was evaluated according to Matta's reduction quality criteria and early postoperative X-rays. A maximum residual displacement level of 0-2 mm was considered anatomical, 2-3 mm - fair and $>3 \mathrm{~mm}$ was graded as poor. X-rays of the anterior 
and posterior pelvis, iliac and obturator oblique were taken during final follow-up visit. X-rays of the anterior and posterior pelvis, iliac and obturator oblique were taken on the same day as the surgery if patients' general condition was good; or after improvement of their general condition if patients' general condition was poor. The reduction quality was assessed and analyzed according to the $\mathrm{X}$-rays. On the basis of the X-rays, a classification was done according to Matta's radiological scoring system (8).

All preoperative, intraoperative and postoperative complications and findings were recorded. Any additional injury was also recorded.

\section{Surgical technique}

All patients were placed supine on the operating table so that Anteroposterior and Judet images could be taken after the stabilization of the posterior component of the fracture. The extremity on the same side and the operating area were covered with a drape. The broken side was slightly flexed to relax the hip and knee, the iliopsoas, external iliac neovascular bundle and the obturator neovascular bundle. The patients had a Foley catheter inserted to monitor fluid balance during surgery and to avoid bladder damage. The surgeon started the operation on the opposite side of the broken side. Using the modified Stoppa approach, surgical penetration was performed $2 \mathrm{~cm}$ proximal to the pubic symphysis with a $12 \mathrm{~cm}$ transverse incision. The linea alba was dissected vertically; the bone was reached by loosening the rectus abdominis on its point of attachment to the pubis. The corona mortis was dissected in all patients and attached with a medium sized clip. The obturator was preserved by locating the neurovascular bundle. The fracture was reduced and fixed with a $3.5 \mathrm{~mm}$ pelvic reconstruction plate and $3.5 \mathrm{~mm}$ cortical screws. In the present study, the lateral window of the ilioinguinal approach was used additionally only for patients with two-column fractures.

\section{Statistical Analysis}

Continuous variables are presented as mean and standard deviation, and categorical variables are presented as absolute numbers and percentages. The Shapiro-Wilk test was used for testing the normality of numerical data. Spearman's rank correlation coefficient was used to test the relationships between numerical variables. The relationship between categorical variables was analyzed by the chi-square test. The SPSS 22.0 software package was used for the analyses. For all analyses, a $p$ value of $<0.05$ was considered statistically significant.

\section{Results}

Fifty-two acetabula from 48 patients who were followed up for at least six months were studied within the scope of the study. The mean age of the subjects was 40.75 ( $15-80$ years) and the mean follow-up time was 9.72 months (6-26 months). Forty (83.3\%) patients were male and eight (16.7\%) were female. The mean time interval between injury and surgery was 5.02 days (2-24 days). Table 1 illustrates the demographic data of the patients included in the study.

The patients had other fractures accompanying their acetabular fractures. Table 2 illustrates these in terms of numbers and percentages.

An examination of the 52 acetabula of 48 patients according to the Judet-Letournel classification showed that the anterior wall fracture was the most frequent form of fracture affecting 16 acetabula (30.7\%), while the least common type of fracture was the anterior column fracture affecting one acetabulum (1.9\%) (Figure 1).

The modified Gibson incision and trochanteric osteotomy were preferred for one $(2 \%)$ patient due to the accompanying fracture of the femoral head. In four $(8.3 \%)$ patients with sacroiliac separation, stabilization was performed with a $3.5 \mathrm{~mm}$ reconstruction plate for the sacrum from the posterior aspect. Following the surgeries, $\mathrm{X}$-rays were taken and the postoperative reduction

\begin{tabular}{|l|l|}
\hline \multicolumn{2}{|l|}{ Table 1. Demographic data of patients } \\
\hline Characteristic & Number of patients (\%) \\
\hline Age (years) & $\mathbf{4 0 . 7 5 ( 1 5 - 8 0 )}$ \\
\hline Sex & $40(83.3 \%)$ \\
\hline Male & $8(16.7 \%)$ \\
\hline Female & $9.72(6-26)$ \\
\hline Follow-up time (months) & \multicolumn{2}{|l|}{} \\
\hline Surgical approach & $10(20.8 \%)$ \\
\hline Modified Stoppa & $33(68.7 \%)$ \\
\hline Modified Stoppa + KL & $3(6.2 \%)$ \\
\hline Modified Stoppa + lateral window & $1(2 \%)$ \\
\hline Modified Stoppa + KL + lateral window & $1(2 \%)$ \\
\hline Modified Stoppa + modified Gibson & \multicolumn{2}{|l|}{} \\
\hline Trauma etiology & $20(41.7 \%)$ \\
\hline Fell from height & $17(35.4 \%)$ \\
\hline Pedestrian injury & $10(20.8 \%)$ \\
\hline Motor vehicle injury & $1(2.1 \%)$ \\
\hline Gunshot wound & \multicolumn{2}{|l}{} \\
\hline KL: Kocher Langenbeck, n: Number &
\end{tabular}

Table 2. Fractures accompanying acetabular fractures

\begin{tabular}{|c|c|c|c|c|c|c|c|c|c|}
\hline Accompanying fracture site & Pelvis & Humerus & Femur & Vertebra & Scapula & Tibia & Clavicula & Radius, ulna & Other \\
\hline Number of accompanying fractures & $11(22 \%)$ & $3(6 \%)$ & $4(8 \%)$ & $3(6 \%)$ & $3(6 \%)$ & $10(20 \%)$ & $2(4 \%)$ & $7(14 \%)$ & $7(14 \%)$ \\
\hline
\end{tabular}


quality was evaluated according to Matta's reduction quality criteria. Accordingly, 29 (60.4\%) patients had an anatomical reduction, $14(29.1 \%)$ a fair reduction and five $(10.4 \%)$ a poor reduction. On the basis of Matta's radiological scoring system evaluation made with standard $X$-rays of the anterior and posterior pelvis, follow-up $X$-rays were very good in 26 acetabula (50\%), good in 11 $(21.2 \%)$, fair in nine $(17.3 \%)$, and poor in six (11.5\%). No significant difference was observed between Matta's radiological criteria and reduction quality criteria values. $(p=0.112)$.

Clinical assessment of patients during the final follow-up visit was made according to the Modified Merle d'Aubigne clinical evaluation criteria. According to these criteria, excellent clinical results were obtained in 38 acetabula (73\%), fair in seven (13.5\%) and poor in seven (13.5\%). A significant correlation was found between the reduction quality assessment performed on the postoperative $X$-rays and the clinical outcomes $(p=0.002)$. At the same time, there was a significant correlation between Matta's radiological criteria and clinical outcomes $(p<0.001)$. While there was no significant correlation between modified Merle d'Aubigne score and age $(r=-0.260, p=0.075)$, there was a moderately negative correlation between length of hospital stay and score $(r=-0.486, p=0.005)$.
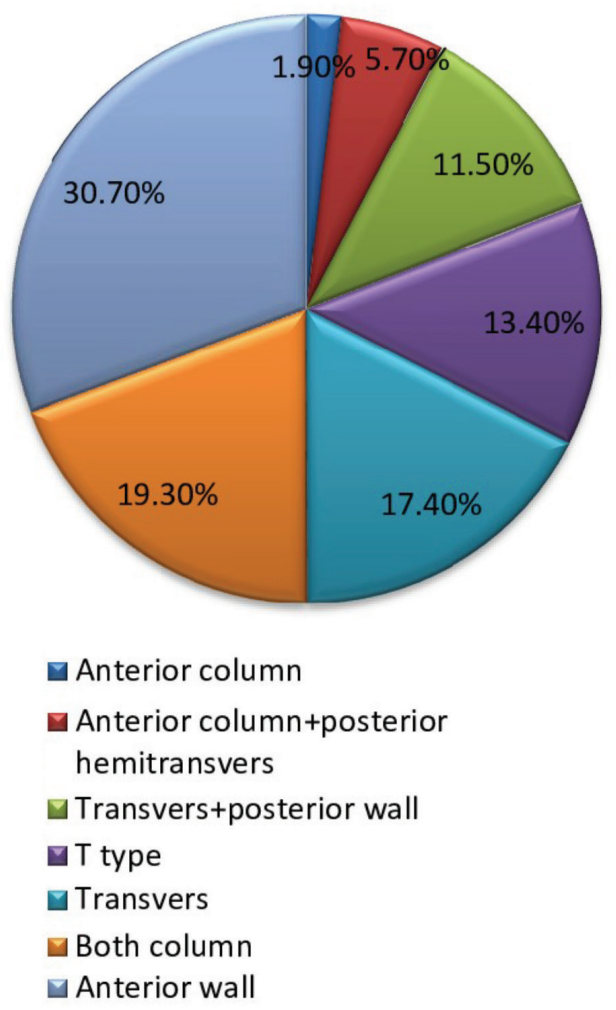

Figure 1. Distribution of fracture types according to the JudetLetournel classification
In this study, two patients had to undergo surgery again due to failure of the first procedure. In one of the patients, an implant failure was noticed during a postoperative follow-up visit; the patient was reoperated and fixation was attempted, but the implant was removed and a conservative treatment was decided because the intra-op bone was osteoporotic. One patient underwent a total hip arthroplasty due to osteolysis of the femoral head and severe hip pain observed during a follow-up examination. In our study, two preoperative patients had total sciatic damage and two patients had peroneal damage. In one postoperative patient, iatrogenic peroneal nerve injury developed and in the postoperative follow-up at month five, it completely resolved. In our series, one (2\%) patient developed surgical site infection that required debridement. Recovery was achieved after debridement and antibiotherapy during patient follow-up.

\section{Discussion}

Acetabular fractures may cause serious limitations and disabilities that can seriously affect daily life activities, work and social life. The main cause of the condition is traffic accidents at a rate of $50-70 \%$ (9). An investigation of the causes of the acetabular fractures in the study revealed that 20 patients (41.7\%) fell from height, 17 patients (35.4\%) had a pedestrian injury, ten patients (20.8\%) had a motor vehicle injury (driver/passenger), and one patient (2.1\%) developed an acetabular fracture following a gunshot injury. Acetabular fractures usually occur after high-impact traumas. For this reason, it is often accompanied by other musculoskeletal and visceral injuries $(10,11)$. In our study, 28 patients (58.3\%) had a concomitant fracture in their extremities. In a series by Matta (3), it was reported that extremity injuries accompanied acetabular fractures in $35 \%$ of patients.

In our study, anterior wall fracture was the most frequent form of fracture affecting 16 acetabula (30.7\%), while the least common type of fracture was the anterior column fracture affecting one acetabulum (1.9\%). According to the literature, the most common type of fracture is two-column fracture as reported in $33.3 \%$ of cases in a study by Matta (2), and posterior wall fracture as reported in $23.6 \%$ of cases in a study by Giannoudis et al. (9). The rarest type of fracture in all studies was anterior wall fracture. The reason why the most common fracture in our study was anterior wall fracture may be the inclusion of patients using the modified Stoppa method. When this method is used, all fractures involving isolated posterior components are excluded from the study.

Determining the time of surgery is important. Many authors have advocated surgery within two to eight days following trauma. In the present study, the mean time to 
surgery was $5.02( \pm 3.72)$ days. According to our clinical experience, surgery should be performed shortly after stabilization of comorbid conditions that prevent surgery and once the patient is stable hemodynamically. According to the data obtained in the present study, the patients' condition worsened according to Merle d'Aubigne criteria as the length of hospital stay was extended for any reason. In our study, the modified Stoppa method was used for all patients. It has been reported that better reduction, fewer complications, shorter operative time, less neurovascular damage and intraoperative blood loss were observed in patients managed with the modified Stoppa method $(12,13)$.

The modified Stoppa approach is also an alternative to the ilioinguinal approach $(14,15)$. In this study, the modified Stoppa approach was combined with the lateral window in four (8.3\%) patients. The combined lateral window approach was used for patients with two column fractures. In a patient series, it was reported that this combination was required in $34(60 \%)$ of 57 patients for fracture reduction and/or fixation (16). In our opinion, the combination of the modified Stoppa approach with lateral window approach is appropriate for patients with a column fracture or an additional iliac wing fracture. Its routine use is not necessary.

In our study, we achieved excellent and good clinical outcomes in $73 \%$ of patients. Of the authors who provided an assessment of clinical outcomes after surgical treatment, Matta (2) and Letournel (4) reported a success rate of $87 \%$ and $84 \%$, respectively. Ruesch et al. (16) reported acceptable results in $81 \%$ of cases (4). Meir Liebergall et al. (17) reported a success rate of $77 \%$.

Clinical outcomes of older patients with acetabular fractures are worse in comparison to younger ones $(18,19)$. In contrast to other studies in the literature, we found no significant difference between patients above 45 and those under 45 years of age in terms of post-operative clinical outcomes, regardless of factors such as fracture type and reduction quality.

The results of hip arthroplasty performed after conservatively treated acetabular fracture or after open reduction procedures are worse in comparison to primary arthroplasty for arthrosis on non-traumatic areas $(20,21)$.

One of the patients in our study underwent total hip arthroplasty due to development of avascular necrosis in the femoral head and hip pain during post-op follow-up. Severe ossification in as many as $50 \%$ of cases has been reported in some patient groups (22). No heterotopic ossification leading to a significant loss of function was found in patients included in our study. Letournel and Judet (23) reported 13 cases of death after acetabular fracture surgery, four of which were due to massive pulmonary thromboembolism. More than $75 \%$ of the cases of pulmonary thromboembolism occur due to DVT in the lower extremities (24). In our study, no patients had symptoms of DVT.

\section{Study Limitations}

First of all, this study is a retrospective study that investigates acetabular fracture treated by modified Stoppa incision. The fracture types are heterogeneous; all fracture types of acetabulum were analyzed. So, we did not evaluate a single fracture group. Our study includes short-term results of acetabulum fractures. On the other hand, we do not know if additional injuries affected the results or not. Also, additional injuries were classified, but we do not know which of them affected results more, for example in the literature it is stated that whether there is an additional fibula fracture with a tibial fracture that could affect the healing time, but in our study, we only investigated whether the patients had additional injuries or not'.

\section{Conclusion}

The modified Stoppa approach may be an alternative to other surgical methods because of less soft tissue damage, effective reduction and stabilization of the fracture, bilateral access through a single incision, less likelihood of damage to the neurovascular bundles, and faster recovery in the postoperative period. It might also be acknowledged as a routine procedure in the future.

\section{Authorship Contributions}

Concept: G.K. Design: G.K. Data Collection or Processing: N.G., T.S. Analysis or Interpretation: N.G., G.K., B.K., T.S., N.Y.S. Literature Search: N.G. Writing: N.G., G.K.

Conflict of Interest: No conflict of interest was declared by the authors.

Financial Disclosure: The authors declared that this study received no financial support

\section{References}

1. Kinik $H$, Armangil $M$. Extensile triradiate approach in the management of combined acetabular fractures. Arch Orthop Trauma Surg 2004;124:476-82.

2. Matta JM. Operative treatment of acetabular fractures through the ilioinguinal approach: a 10-year perspective. J Orthop Trauma 2006;20:S20-9.

3. Matta JM. Fractures of theacetabulum: accuracy of reduction and clinical results in patients managed operatively within three weeks after the injury. J Bone Joint Surg Am 1996;78:1632-45.

4. Letournel E. The treatment of acetabular fractures through the ilioinguinal approach. Clin Orthop Relat Res 1993;292:6276. 
5. Alonso JE, Davila R, Bradley E. Extended iliofemoral versus triradiate approaches in management of associated acetabular fractures. Clin Orthop Relat Res 1994;305:81-7.

6. Helfet DL, Schmeling GJ. Management of complex acetabular fractures through single nonextensile exposures. Clin Orthop Relat Res 1994;305:58-68.

7. D'aubigne RM, Postel M. Functional results of hip arthroplasty with acrylic prosthesis. J Bone Joint Surg Am 1954;36-A:45175 .

8. Matta JM, Mehne DK, Roffi R. Fractures of the acetabulum. Early results of a prospective study. Clin Orthop Relat Res 1986;241-50.

9. Giannoudis PV, Grotz MR, Papakostidis C, Dinopoulos H. Operative treatment of displaced fractures of the acetabulum. A meta-analysis. J Bone Joint Surg Br 2005;87:2-9.

10. Kregor PJ, Templeman D. Associated injuries complicating the management of acetabular fractures: review and case studies. Orthop Clin North Am 2002;33:73-95.

11. Moed BR, Yu PH, Gruson KI. Functional outcomes of acetabular fractures. J Bone Joint Surg Am 2003;85:1879-83.

12. Meena S, Sharma PK, Mittal S, Sharma J, Chowdhury B. Modified Stoppa Approach versus Ilioinguinal Approach for Anterior Acetabular Fractures; A Systematic Review and Meta-Analysis. Bull Emerg Trauma 2017;5:6-12.

13. Wu H, Zhang L, Guo X, Jiang X. Meta-analysis of modified Stoppa approach and ilioinguinal approach in anterior pelvic ring and acetabular fractures. Medicine (Baltimore) 2020;99:e18395.

14. Andersen RC, O'Toole RV, NasconeJW, Sciadini MF, Frisch HM, Turen CW. Modified stoppa approach for acetabular fractures with anterior and posterior column displacement: quantification of radiographic reduction andanalysis of interobserver variability. J Orthop Trauma 2010;24:271-8.
15. Jain M, Kumar P, Tripathy SK, Behera S, Rana R, Das S. Clinicoradiological Outcomes of Using Modified Stoppa Approach for Treating Acetabular Fractures: An Institutional Review. Cureus 2020;12:e7821.

16. Ruesch PD, Holdener H, Ciaramitaro M, Mast JW. A prospective study of surgically treated acetabular fractures. Clin Orthop Relat Res 1994;305:38-46.

17. Liebergall M, Mosheiff R, Low J, Goldvirt M, Matan Y, Segal D. Acetabularfractures. Clinicaloutcome of surgical treatment. Clin Orthop Relat Res 1999;366:205-16.

18. Mears DC, Velyvis JH, Chang CP. Displaced acetabular fractures managed operatively: indicators of outcome. Clin Orthop Relat Res 2003;407:173-86.

19. Olson SA, Rhorer AS. Orthopaedic trauma for the general orthopaedist: avoiding problems and pitfalls in treatment. Clin Orthop Relat Res 2005;433:30-7.

20. Henry PDG, Si-Hyeong Park S, Paterson JM, Kreder HJ, Jenkinson R, Wasserstein D. Risk of Hip Arthroplasty After Open Reduction Internal Fixation of a Fracture of the Acetabulum: A Matched Cohort Study. J Orthop Trauma 2018;32:134-40.

21. Capone A, Peri M, Mastio M. Surgical treatment of acetabular fractures in the elderly: a systematic review of the results. EFORT Open Reviews 2017;2:97-103.

22. Bosse MJ, Poka A, Reinert CM, Ellwanger F, Slawson R, McDevitt ER. Heterotopic ossification as a complication of acetabular fracture. Prophylaxis with low dose irradiation. J Bone Joint Surg Am 1988;70:1231-7.

23. Letournel E, Judet R. Fractures of the Acetabulum. 2nd ed. New York: Springer-Verlag; 1993.

24. Elias A, Colombier D, Victor G, et al. Diagnostic performance of complete lower limb venous ultrasound in patients with clinically suspected acute pulmonary embolism. Thromb Haemost 2004;91:187-95. 